\title{
ОСНОВНІ ПРОБЛЕМИ ПІД ЧАС ПІДГОТОВКИ КУРСАНТІВ ДО МОВНОГО ТЕСТУВАННЯ ЗА СТАНДАРТОМ НАТО STАNАG 6001 ТА МОЖЛИВІ ШЛЯХИ ЇХ ВИРІШЕННЯ
}

\begin{abstract}
Анотація. Стаття присвячена актуальності підготовки курсантів-старшокурсників до мовного тестування за стандартом HATO STANAG 6001. Субтест складається з чотирьох видів мовленнєвої діяльності аудіювання, говоріння, читання та письма. Оскільки особливі проблеми у випускників виникають під час складання тесту з продуктивних видів мовленневої діяльності, тобто говоріння та письма, то слід приділити увагу розвитку саме цих видів. В статті наводяться приклади завдань для розвитку навичок говоріння та письма на основі комунікативного методу для курсантів різних рівнів володіння англійською мовою. Також розглядаються деякі проблеми, з якими стикаються викладачі при викладанні англійської мови в групах на старших курсах. В кінці статті підкреслюеться необхідність складання методичних розробок для навчання старшокурсників навичкам говоріння та письма.
\end{abstract}

Ключові слова: мовне тестування за стандартом HATO STANAG 6001, розвиток навичок читання та письма, комунікативний метод, продуктивні види мовленневої діяльності, презентація лексики, активний словниковий запас.

\author{
Svetlenko Maia \\ Military Academy (Odessa)
}

\section{MAIN PROBLEMS WHILE PREPARING CADETS FOR THE LANGUAGE TESTING NATO STANAG 6001 AND POSSIBLE WAYS OF THEIR SOLVING}

Summary. The article deals with the necessity of preparation of senior cadets for the language testing NATO STANAG 6001. The test consists of four parts: listening, speaking, reading and writing. The main problem is that according to the curriculum, cadets learn general English during the first years, and during the last years they have military English. But to pass the test they need general English. The most problems appear while passing speaking and writing tests, where the cadets need productive skills. That is why the teachers should develop speaking and writing skills during the English lessons. It is necessary to use different forms of work in the classroom - open class, group work, pair work, individual work. There are cadets of different levels in each group and teachers often don't have enough time to pay attention to all cadets. That is why sometimes the teacher can give some written tasks to the whole class and work with lower cadets individually. Examples of oral and written tasks of different levels are given in the article, so the teacher can give different activities in one group at the same time. All activities are based on the communicative method. According to this method, the structure of the lesson consists of 3 main parts - presentation, practice and production. If we teach our cadets vocabulary, we can use different activities for each stage. In the article the author describes some ways of vocabulary presentation, advises interesting games for practice and production stages. In the article it is also underlined that it is very important for the teacher to give the right error correction. During production, when students are involved in speaking activity such as a role-play or conversation, it is very important to pay attention on fluency, that is why the teachers shouldn't correct the cadets on spot and interrupt them during speaking. During the lesson, peer correction and self-correction can also be used. When the teacher corrects too much in the written tasks, it can have a demotivating effect. That is why it is better to underline mistakes and use special symbols or in one work correct only spelling or grammar mistakes. In the end of the article it is underlined the necessity for teachers to create some booklets with activities of different levels to develop speaking and writing skills.

Keywords: language testing NATO STANAG 6001, development of speaking and writing skills, communicative method, productive types of speech, vocabulary presentation, active vocabulary.

Постановка проблеми. На даному етапі 1 реформування та розвитку Збройних Сил України актуальною стає мовна підготовка особового складу до мовного тестування за стандартом HATO STANAG 6001, яка здійснюеться згідно з Основними засадами мовної підготовки особового складу у системі Міністерства оборони України. Реалізацію Основних засад передбачаеться здійснити двома етапами протягом 2019-2030 років.

Перший етап (2019-2024 роки) е перехідним до другого, під час цього етапу продовжуються впроваджуватись заходи щодо посилення системи мовної підготовки особового складу Збройних Сил України, розробляються типові навчальні програми з вивчення іноземних мов у ВВНЗ та ВНЗ ЗВО, збільшуеться кількість годин до 580 для військових фахівців тактичного рівня.

На другому етапі (2025-2030 роки) передбачаеться обов'язкове володіння англійською мовою на рівні не нижче СMP 2 (Функціональний) (CMP стандартизований мовленневий рівень) для військовослужбовців та працівників Збройних Сил України при просуванні по службі на певні посади, перехід ВВНЗ та ВНЗ ЗВО на нові навчальні програми для забезпечення випускниками мовної підготовки не нижче CMP 2 [6, с. 2].

Аналіз останніх досліджень і публікацій. Відомі зарубіжні методисти, які розглядають комунікативний метод викладання іноземних мов, - це Джеремі Хармер, Пенні Ер, Скот 
Торнбері, Пітер Вотчін-Джонс, Крис Баркер, Дж.Дж. Вілсон, Джеральд Кері, Вірджініа Френч Аллен, Давід Сеймур та інші. На відміну від граматико-перекладного методу, який був поширений у XX столітті у нашій країні, комунікативний метод, який все більше поширюеться у багатьох країнах світу, має за основу не правильні граматичні структури, заучування діалогів та фрраз, а індукцію, тобто правила виводяться студентами, які не пасивно сприймають інформацію, а є активними учасниками процесу навчання. Головна мета - це досягти комунікацію різними способами. Вчитель виступає другом, порадником, направляе студентів на правильний шлях. Велика увага приділяеться груповій та парній роботі.

Виділення не вирішених раніше частин загальної проблеми. Мовний тест складаеться 3 чотирьох субтестів - 3 аудіювання, говоріння, читання та письма. Під час підготовки курсантів до мовного тестування перед викладачами постає кілька проблем. По-перше, вступне тестування показуе, що рівень знань англійської мови абітуріентів з кожним роком залишае бажати кращого. Звичайно, є курсанти з доволі високим рівнем володіння англійською мовою та мотивовані курсанти, які працюють перекладачами, приймають участь в різних заходах, таких як олімпіади та конференції, їздять за кордон, але відсоток таких курсантів, на жаль, невеликий.

По-друге, згідно з сучасною програмою, курсанти вчать побутову лексику на 1-2 курсах, а на старших вони вивчають військову термінологію. Але під час тесту з говоріння вони мають відповідати на питання з таких тем як сім'я, робота, дозвілля, подорожі, освіта, одяг, їжа та напої, житло, погода тощо. Суб̆тест з письма також в основному має загальновживані теми, такі як повідомлення, вітальна листівка, звіт, розповідь, рапорт тощо. Тому до навчальної програми на старших курсах слід додати теми з побутової лексики [6, с. 12, 18].

3 цього постае актуальність підготовки курсантів до мовного тестування. Аудіювання та читання є рецептивними видами мовленневої діяльності. Для розуміння аудіо тексту або написаного тексту той, кого тестують, може використовувати інтуїцію, мовну здогадку про значення незнайомих слів з контексту, за допомогою знайомих словотворчих елементів, малюнків, графріків, знаків, схем. Навички зі сприйняття мовлення на слух можна розвинути самостійно під час перегляду фільмів, слухаючи пісні, аудіо книги, радіо. Поповнити словниковий запас можна також самостійно, читаючи різні книги та статті англійською мовою. Для цього Інтернет зараз надае великі можливості.

Найбільші проблеми виникають з продуктивними видами мовленневої діяльності, такими як письмо та говоріння, які самостійно практично неможливо тренувати. Для цього потрібен реципіент, який би не тільки отримував повідомлення, але б також виправляв помилки та надавав поради щодо покращення цих навичок, тобто т'ютер, яким звичайно е викладач в аудиторії. Тому під час викладання іноземної мови на занятті слід звертати увагу на розвиток навичок письма та говоріння.

Мета статті. Основною метою цієї роботи e розгляд деяких способів, за допомогою яких під час занять з іноземної мови на старших курсах готувати курсантів до здачі мовного тестування за стандартом HATO STANAG 6001, особливу увагу приділяючи розвитку продуктивних навичок мовленневої діяльності, таких як говоріння та письмо.

Виклад основного матеріалу дослідження. Для розвитку навичок письма дуже часто викладачі надають письмові завдання курсантам для самостійної роботи дома, отримують завдання в письмовому або в електронному вигляді на наступному занятті, перевіряють та пишуть "feedback". Звичайно, великим плюсом цього є економія часу на занятті та отримання більш розгорнутих письмових відповідей. Але самостійність цих завдань е сумнівною. Викладач не знае, якими матеріалами користувався курсант під час написання твору і чи він писав цей твір самостійно.

Тому краще виділяти 15-20 хвилин на занятті на написання коротких листів. Хай за розміром вони будуть невеликі, але викладач точно буде знати, що курсанти нічим не користувались під час цього завдання, що кожний писав самостійно. Можна дати їм тему для підготовки на самостійну роботу, пошукати певну інформацію та скласти план листа, але само написання краще провести на занятті. Перевірити та написати "feedback" викладач може після заняття [2, с. 31-34].

Якщо група складається з курсантів з високим рівнем знань англійської мови, то можна виділити ще трохи часу для взаємоперевірки листів курсантами з підкресленням помилок та зауваженнями, а потім обговорити типові помилки на наступному занятті. 3 практики проведення мовного тестування, найбільші проблеми виникають з порядком слів у реченнях, правильним вживанням граматичних структур, орфографією і пунктуацією. На це слід звертати увагу під час розвитку навичок письма.

Багато курсантів думають або говорять, що вони не можуть, або не хочуть писати. Причиною цього може бути невпевненість, вони можуть вважати письмо нудним або гадати, що їм нема, що сказати. Тому викладачам слід зацікавити курсантів, починаючи 3 початківців, легкими та цікавими завданнями, щоб письмо стало не тільки звичайною частиною заняття, але також можливостями для досягнення успіху [1, с. 113].

Слід розрізняти письмо для навчання та письмо для письма. В першому випадку письмо допомагае практикувати вивчену граматичну структуру або нову лексику. Можна дати, на приклад, завдання - скласти 5 речень 3 певною граматичною структурою або вивченими словами. Також письмо для навчання може бути, коли курсанти пишуть речення, щоб підготуватись до іншої вправи [1, с. 112].

Письмо для письма розвиває навички курсантів як письменників, який би вид письма це не був. Для розвитку навичок письма можна використовувати написання електронних листів, поштових карток, листів та доповідей, відповідей на рекламні оголошення [1, с. 112].

Тип письмових завдань, які надаються курсантам, залежить від їхнього віку, інтересів та рівня володіння іноземною мовою. Коли ми надаємо завдання початківцям, ми маємо бути 
впевненими, що курсанти володіють достатнім словниковим запасом для виконання вправи [1].

Починати навчанню навичкам письма слід 3 пояснення структури листів, відмінностей між офріційними та неофіційними листами. Першим завданням може бути написання поштової листівки 3 місця відпочинку. Викладач надає зразок поштової листівки, курсанти визначають структуру листівки, стиль, граматичний час використаних фрраз, знаки пунктуащії. Після цього можна дати написану листівку, але без знаків пунктуації, які треба вставити, потім з деякими орфографічними помилками, потім - 3 граматичними, потім з пропусками, які треба заповнити поданими внизу словами, в кінці - 3 пропусками, але які треба заповнити своїми власними варіантами [1, с. 80-81].

Дуже корисною є вправа на пошук орфографрічних помилок - спочатку в окремих фрразах та реченнях, потім - листах. Курсанти вчаться бути уважними та знаходити помилки у власних роботах. Потім можна переходити до пошуку граматичних помилок, слів, які порушують стиль. На вищих рівнях курсанти можуть шукати заміну слів синонімами різної конотації - нейтральної, позитивної або негативної в залежності від стилю письма [3, с. 38-42].

Тепер можна переходити до самостійного написання листівки. Курсантам треба уявити, що вони знаходяться в якомусь місті та написати листівку за зразком. Цікавіше буде, якщо вони будуть витягувати малюнки чи фото з видами різних міст світу та короткою індрормацією та писати один одному листівку з цього міста. Потім сусід має прочитати листівку та підкреслити помилки, якщо він їх побачить. Взагалі можна дуже часто проводити взаємоперевірку, щоб курсанти вчились звертати увагу на помилки, що їм стане у нагоді, коли вони будуть писати листи під час тестування.

Потім можна починати диктанти листів. Спочатку можна давати роздатковий матеріал 3 готовими листами, які містять пропуски, з кожним разом пропусків має бути більше, доки не буде диктант всього тексту. Якщо в групі курсанти володіють різним рівнем знань англійської мови, то можна давати роздатковий матеріал для написання листа в залежності від рівня курсантів. Найсильніші курсанти отримують чистий аркуш, на якому пишуть весь текст. Середні курсанти отримують текст 3 великою кількістю пропусків, найслабші - небагато пропусків, але на наступних заняттях кількість пропусків має збільшуватись.

Наступним етапом може бути завдання закінчити речення. Викладач роздає курсантам листи, в яких написана лише перша половина кожного речення, і вони мають закінчити речення своїми власними думками.

Також курсанти середнього рівня можуть писати так звані “altering dictations", де вони мають змінити твердження в залежності від своїх власних уподобань та пріоритетів. Наприклад: "Human beings do not treat animals well”, курсанти переписують речення згідно зі своїми власними думками. Потім можна в парах або групах дійти компромісу між різними точками зору [1, с. 81-82].

Наступний приклад, який наводить методист, це - написання газетних статей, але для підго- товки до мовного тестування нас більше цікавить написання доповідей для курсантів вищого рівня. Для цього виду письма потрібна підготовка - пошук інформації, складання плану доповіді. Викладач також має пояснити структуру написання доповіді, особливості стилю [1, с. 82-84].

А для початківців та курсантів середнього рівня наступним етапом може бути написання листів на задану тему. Щоб зробити процес написання листів цікавішим, курсанти можуть писати листи не якомусь незнайомому другу, а сусіду за партою, на який він має відповісти. Наприклад, перший лист: Запросити друга на святкування дня народження, визначити дату та місце проведення вечірки. Лист-відповідь: Подякувати за запрошення, відмовитись, пояснити причину відмови та написати, коли можлива зустріч.

Ще один приклад. Перший лист: Запросити друга в своє рідне місто, написати, яка там погода зараз, який одяг брати, які цікаві місця можна відвідати. Лист-відповідь: Подякувати за запрошення, написати дату та час прибуття, попросити зустріти на вокзалі та порекомендувати житло.

Офріційні листи також можна писати один одному. Перший приклад: 1) оголошення про пошук працівника, вимоги та умови роботи; 2) написання листа-резюме; 3) позитивна або негативна відповідь роботодавця. Другий приклад: 1) оголошення про здачу квартири в оренду, умови проживання та вимоги до орендаря; 2) написання листа хазяїну квартири, описати себе та поставити додаткові запитання про умови проживання; 3) відповісти на лист - домовитись про зустріч або відмовити.

Таким чином, курсанти будуть писати листи не для викладача, а мати комунікативну мету. Кожний курсант пише спочатку оголошення (структуру та зразок треба розібрати перед написанням листів), а потім два листа, в яких виступає спочатку адресантом, а потім адресатом. Перевірити листи викладач може дома після заняття, а потім обговорити типові помилки на наступному.

На думку вченого, коли викладач виправляє усі помилки та повертає курсанту лист, червоний від виправлень, це де мотивуе курсанта та має негативний вплив на його бажання виконувати письмові роботи в майбутньому. Для запобігання цього викладачам слід попередити курсантів, що в певній роботі вони будуть виправляти помилки лише з пунктуащії, орфографії або граматики і т.д. Це має дві переваги: примушує слухачів концентруватись на певному аспекті та зменшуе виправлення помилок [1, с. 84].

Ще одна техніка перевірки письмових робіт домовитись 3 курсантами про список письмових символів ( $\mathrm{S}$ - spelling, WO - word order) і т.д. Викладачі підкреслюють помилку та пишуть символ на полях, а курсанти самостійно виправляють їі.

Також можна логічно продовжити тему говоріння написанням листа. Наприклад, якщо на занятті обговорювалась тема «Погода, улюблена пора року», то заняття можна закінчити листом на тему «Клімат мого регіону». Якщо обговорювали тему «Мій улюблений вид транспорту», то можна написати лист «Види транспорту мого міста». I таким чином можна закінчувати будь-яку тему.

Викладачі, в основному, визначають певні часові рамки для написання листів - наприклад, 
10 речень за 20 хвилин. А що робити, якщо одні вже закінчили письмову роботу, і не знають, чим зайнятись, а інші не вклались в часові рамки і їм потрібно ще декілька хвилин? Якщо їх чекати, то чим зайняти тих, хто вже написав? А якщо не чекати, а збирати роботи своєчасно, то слабкі курсанти постійно не будуть встигати закінчити лист, що буде мати негативний демотивуючий ефект.

На нашу думку, якщо посадити разом курсантів 3 однаковим рівнем, то сусіди з вищим рівнем приблизно одночасно закінчать роботу і їм можна буде дати додаткове завдання. Це може бути взаємоперевірка листів, а решту викладач перевірятиме сам після заняття. Або курсантам можна дати якусь усну тему для обговорення в парах, яка пов'язана з темою листа, а потім зробити висновки перед усією групою, коли всі допишуть. Також найсильнішім курсантам, які вважають, що вони все знають, можна дати завдання пошукати додаткову лексику до теми в словниках, щоб кожна пара знайшла по 5 додаткових слів, які будуть новими для решти. I після того, як всі закінчать писати листи, ці курсанти можуть написати знайдені слова на дошці для всієї групи.

Це буде мати одразу декілька результатів. Поперше, активний словниковий запас всієї групи 3 теми заняття збільшиться ще на 5-10 слів. Подруге, сильним курсантам буде чим займатись, може вони також вивчать пару нових слів. Потретє, слабкі курсанти допишуть лист до логічного кінця і побачать, що вони також на щось здатні. А якщо їм кожного разу не давати дописати лист, тому що час вичерпано, то вони так ніколи і не навчаться цього робити.

Наступним видом мовленнєвої діяльності, на який треба звернути увагу - це говоріння. Найбільші труднощі, з якими стикаються курсанти під час говоріння - це, так званий, «мовний бар'єр», страх зробити помилки, через що страдає вільність мовлення, невеликий активний словниковий запас, неправильне використання граматичних структур, неправильна вимова деяких слів.

Якщо на перших курсах слід більш уваги звертати на правильне вживання граматичних структур та на розширення активного словникового запасу, то на старших курсах треба сприяти вільному мовленню [1, с. 94].

По-перше, викладачу слід створити «англійську атмосферу в класі», намагатись не використовувати рідну мову - давати всі накази, інструкції, пояснення англійською, «чути» лише англійську, намагатись уникати перекладу та використовувати малюнки, жести, синоніми, антоніми, описи.

По-друге, викладачу слід спонукати курсантів до говоріння, створювати цікаві завдання, використовувати рольові ігри, інтерв'ю, дискусії, в залежності від рівню та інтересів групи.

Викладачу не слід перебивати курсанта під час говоріння та виправляти помилку на місці, тому що це знищить мету говоріння. Краще дослухати курсанта до кінця, зробити нотатки основних помилок та обговорити їх після завдання. Типові помилки для більшості курсантів можна записати на дошці.

Також курсанти можуть виправляти один одного (також після висловлювання) - peer correction, або виправляти себе - self-correction.
Це також є дуже корисним - слухати та помічати помилки у своїх товаришів та у себе. Головне, щоб була створена дружня атмосфрера, щоб курсанти не ображали один одного пошуками помилок.

Згідно з комунікативним методом викладання іноземних мов, структура заняття звичайно складається з розминки, вступу, презентації, практики та продукування. У вступній частині (Leadin) викладач вводить тему заняття за допомогою вступних запитань. Презентувати нову лексику можна двома способами. 1. Спочатку значення (малюнок), потім форма - назвати слово та показати написання та транскрипщію. 2. Спочатку форма - написане слово, вимова та транскрипція, потім - значення - малюнок, контекст і т.д.

Для презентації нової лексики можна використовувати безліч різних вправ - з'єднувати слова-малюнки-визначення, мозковий штурм, «дерева» слів, міміка, жести, контекст, синонімиантоніми.

Оскільки старшокурсники на молодших курсах вже вчили основну лексику до повсякденних тем, то їм потрібно цю лексику повторити та доповнити для розширення активного словникового запасу. Тому найкращим способом презентащії лексики буде мозковий штурм, щоб курсанти диктували викладачу лексичні одиниці, які вони знають, а він вже записував у вигляді дерева, сонця або за групами, наприклад наземний, морський та повітряний транспорт, або їжа - означені та неозначені іменники. В сильніших групах курсанти можуть по черзі виходити до дошки, записувати слова самостійно та знаходити помилки [5, с. 76-81].

Для засвоєння лексики можна також використовувати безліч цікавих вправ та ігор - правильно-неправильно, складання речень, запитань, заповнення пропусків, бінго, анаграми, шибениця, кросворди, хрестики-нолики, загадки, морський бій та багато інших. На старших курсах можна використовувати по-одному завданню для практики, на кожному занятті інше, тому що якщо кожного разу давати, наприклад тільки правильно-неправильно або заповнення пропусків, то це буде не дуже цікавим. А якщо робити вправи у командах, хто раніше та правильніше, то це принесе найбільш задоволення [5, с. 93-98].

Для продукування існуе також багато вправ ролеві ігри і симуляціі, інтерв’ю, розповідь історій, жартів, порівняння, вирішення проблем, дискусії, дебати, ігри на виживання та інші. В залежності від рівня групи на різних заняттях можна використовувати різні вправи [5, с. 100-105].

Існують різні форми роботи в класі - робота у цілому класі, групова робота, парна робота, індивідуальна робота. Звичайно, парна робота при обговоренні певної теми економить час та дає кожному з курсантів більшість часу для висловлення. Але при такій роботі викладач не може охопити всі помилки кожного курсанта і має уяву тільки про типові помилки усієї групи [4, с. 73].

Проте, на старших курсах в слабких групах часто треба приділити увагу кожному курсанту окремо та ретельно обговорити його помилки індивідуально. А оскільки основна увага програми приділяеться військовій термінології, на яку в слабких групах також витрачається багато часу, то на те, щоб вислухати кожного курсанта окремо, просто не залишається часу. 
Єдиним виходом, на нашу думку, є паралельна робота - одне письмове завдання з військової теми заняття - наприклад, читання тексту та заповнення пропусків, відповіді на запитання до тексту або пошук правильних - неправильних відповідей. Або може бути завдання - написати лист, пов'язаний з усною темою, про що йшла мова вище. Коли письмова робота буде виконана, курсанти можуть зробити взаємоперевірку.

Коли вся група буде працювати над певним письмовим завданням, у викладача з'явиться час для усного індивідуального опитування курсантів - слухати розповідь на певну тему, відповіді на запитання, а потім обговорювати кожну помилку. Якщо на інтерв'ю з кожним курсантом використати хоча 65 хвилин на кожному занятті, то буде значний результат.

Якщо в групі курсанти мають різний рівень володіння англійської мови, то сильні курсанти можуть обговорювати певну тему в парах, а слабкі - працювати індивідуально з викладачем. Або можна поділити курсантів на пари - сильний та слабкий. Слабкий відповідае, сильний записуе помилки, які почув, потім виправляе. Потім сильний курсант відповідае, а слабкий ставить запитання. Головна умова - не перебивати один одного, всі помилки та зауваження записувати, потім озвучувати.

Таким чином, викладачам ВВНЗ та ВНЗ ЗВО на старших курсах слід приділяти увагу розвитку говоріння та письма на загальні теми для підготовки курсантів до мовного тестування за стандартом HATO STANAG 6001, щоб забезпечити мовну підготовку особовому складу Збройних Сил України. Пропозиціями може бути складання методичних розробок для навчання старшокурсників навичкам говоріння та письма під час підготовки до мовного тестування.

\section{Список літератури:}

1. Harmer, J. How to teach English: Series for teachers. Oxford : Pearson Education limited 2007, Sixth impression 2010. 290 p.

2. Harmer, J. How to teach Writing: Series for teachers. Oxford : Pearson Education limited 2007. 162 p.

3. Purland M. Big activity book. Intermediate/Level 1. English Banana, 2004. 133 p.

4. Thornbury S. How to teach Speaking: Series for teachers. Oxford : Pearson Education limited 2005. 160 p.

5. Thornbury S. How to teach Vocabulary: Series for teachers. Oxford : Pearson Education limited 2002. Fifth impression 2007. $191 \mathrm{p}$.

6. Порядок проходження мовного тестування. URL: https://nuou.org.ua/u/stru/centers/nnc-im/por-proh-mov-test.html

\section{References:}

1. Harmer J. (2010) How to teach English: Series for teachers. Oxford: Pearson Education limited 2007, Sixth impression, $290 \mathrm{p}$.

2. Harmer J. (2007) How to teach Writing: Series for teachers. Oxford: Pearson Education limited, 162 p.

3. Purland M. (2004) Big activity book. Intermediate/Level 1. English Banana, 133 p.

4. Thornbury S. (2005) How to teach Speaking: Series for teachers. Oxford: Pearson Education limited, 160 p.

5. Thornbury S. (2007) How to teach Vocabulary: Series for teachers. Oxford: Pearson Education limited 2002, Fifth impression, $191 \mathrm{p}$.

6. Poriadok prokhodzhennia movnoho testuvannia. URL: https://nuou.org.ua/u/stru/centers/nnc-im/por-prohmov-test.html 